\title{
The Critical Discourse Analysis on Pornography News of "V Garut" at TribunJabar.id Online Media
}

\author{
ZIKRI FACHRUL NURHADI \\ NENENG CUCU MARLINA \\ MOCHAMAD FIRDAUS \\ Universitas Garut, Indonesia
}

\begin{abstract}
The emergence of pornography cases that had gone viral on social media with the tagline "V Garut" shocked the public because the act was committed by a woman and several men. The female suspect claimed that this act was done because of coercion and pressure that the male suspect had put on her. The research aims to explain the level of text, social cognition and social context of the pornography news of "V Garut" on the online media of TribunJabar.id. The research used a qualitative descriptive method with the theoretical approach of critical discourse analysis by Teun A. Van Dijk. Data collection techniques used observation, interviews, and documentation. The research object was related to the news of " $V$ Garut" on the online media TribunJabar.id with two informants. The results of research at the text level in the elements of macrostructures, superstructures and microstructures explain the existence of a discourse indicating an unfavourable situation such as violence and marginalization on the role of " $V$ Garut". Journalists' social cognition tends to judge this case as "unique" phenomenon, not focusing on a social issue that must be addressed in society. Based on the analysis of the social context of this news, it can be seen that there is a powerful practice of the media and the authority's access in reporting the "V Garut" case.
\end{abstract}

Keywords: Critical discourse analysis, pornography, social cognition, social context, text.

\section{INTRODUCTION}

In August 2019, an immoral violation case happened in Garut Regency West Java, the sexual activity was recorded and widely spread through various social media platforms. The incident went viral on social media in Indonesia and became a public talk. The sexual activity was unnatural or abnormal because it was done by one woman with several men and one of the men was believed as the female suspect's husband. In addition, her husband allegedly sold his wife to the public through social media Twitter, claiming he needed money. The female suspect's husband sold his wife at a rate of five hundred thousand rupiah to seven hundred thousand rupiah for one sexual intercourse (Tribunnews.com, 2019). This incident shocked the public for a long time because the video publicly shared on social media was out of common sense. A nineteen years old woman (female suspect) and studied in junior high school education confessed at Garut Police Headquarter that she was forced to have this abnormal sexual relationship by her husband (Tribunnewswiki.com, 2019).

Literally, pornography means writing about prostitution. In ancient Greek, pornography is taken from the words Porne and Graphein. The Ancient Greeks used the word Porne as a euphemism which means something that is sold. This understanding is connected with the word Pernemi which means to sell. The Ancient Greeks used the word Pernemi to denote the male duty of recording skilled female prostitute. Etymologically, the definition of pornography is related to the documentation or recording of female sex workers (Peter \& Valkenburg, 2016). 
Minister of Women Empowerment and Child Protection of the Republic of Indonesia, Yohana Yembise, in a coordination event for the implementation of the child pornographyfree village model in September 2019 said that globally the trend of children being victims of pornography continues to increase significantly. Data from NCMEC CiberTipline states that there are more than 7.5 million reports of child exploitation in the last 20 years and a rapid increase in the last five years. Meanwhile, "Trends in Online Child Sexual Abuse Material" states that in 2018 the presence of pornographic material has increased rapidly and widely spread online (Tribunnews.com, 2019). Likewise, the complaints received by the Ministry of Information and Communication from the public are 431,065 reports from various complaints received, the majority of the content related to various pornographic are 244,738 public reports. The report was received from the public in 2019, the complaint was received through the aduankonten.id page and Twitter service.

Since this pornography case occurs among adolescents, the emotional and behavioural problems of adolescents are quite serious because they are affected by psychological development (Peter \& Valkenburg, 2016). Various psychosocial stressors are often associated with the emotional and behavioural problems in adolescents such as physical illness, conflict and maladaptive behaviour such as drug abuse and pornographic media addict (Boumosleh \& Jaalouk, 2017). Pornography, which has grown rapidly in Indonesia, is a contributor to psychosocial problems. The pornographic display includes image, writing, sound, video, gesture, or other forms of communication messages aiming at stimulating sexual desire.

Violence against children and women in Garut district was quite high, of the 353 cases that occurred and were handled by the General Criminal Section of the Garut District Prosecutor's Office, there were 34 cases of violence against children and women. Based on the number of cases, there were 18 cases of violence against women and 16 cases against children. Cases of violence against children and women are quite sticking out in 2019 as data from the Garut District Attorney (TribunJabar.id, 2019). Based on the 2019 Annual Notes of the National Commission on Violence against Women (Komnas Perempuan), cases of violence against women that occurred in Indonesia also increased from the previous year, recording that 406,178 cases of violence against women were reported and handled, and previously there were 348,466 cases of violence, increasing 14 per cent. From 13,568 cases of violence against women were handled by 209 partner institutions of the National Commission for Women throughout the Indonesian Province and 329,610 cases of violence against women were handled by the Religious Courts (Tribunnews.com, 2020).

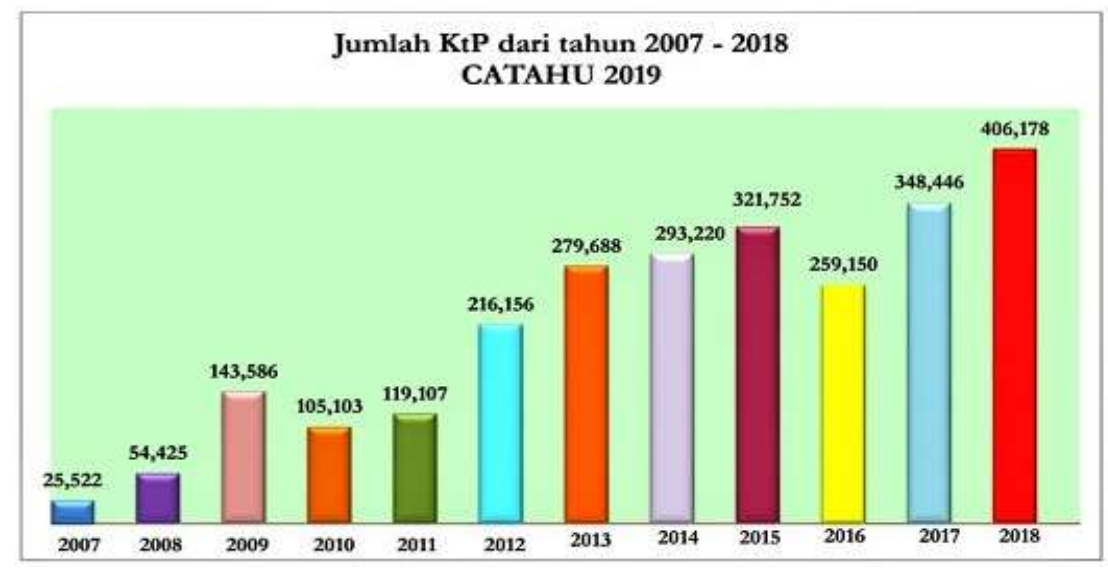

Figure 1: Violence case against woman from 2017-2018 and 2019 annual record 
Violence against women has several dimensions, physical, sexual, psychological, and economic. It is interrelated which affects women from birth to old age (Ybarra \& Mitchell, 2014). The patterns of violence have also changed along with the developments formed, from domestic violence to human trafficking that has looked down the humanity value. The role of women decreases and impoverishes them so that the human capacity to develop decreases (Susilo, 2015).

Based on the explanation, the focus of this research is on the news that is taken from the news of TribunJabar.id related to "The Misfortune Story of V Asked by Husband to Serve Many Men \& Recorded, If She Refused, She was Scolded \& Forced to Enjoy" August and September 2019 editions, as seen in figure 2 .

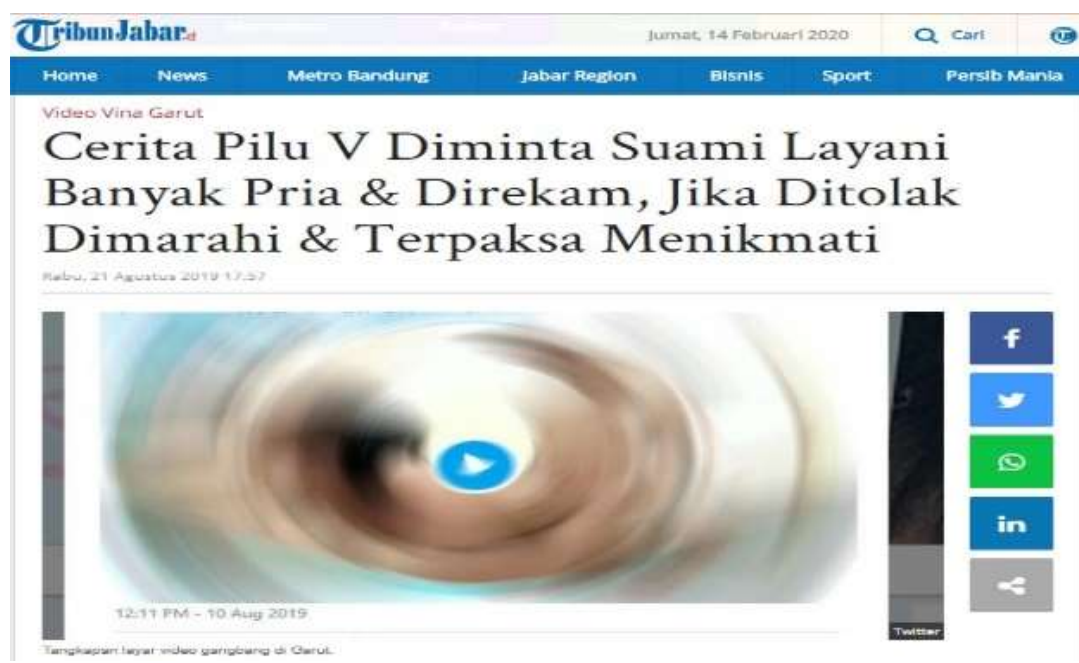

Figure 2: Discourse on the violence of the "V Garut" case

TribunJabar.id. The video of Vina Garut shocked the public after being shared last week. Suspect $V$ also gave comment responding to her nasty video. The woman, who was only 19 years old, married suspect $A$ or Rayya in 2015. She admitted that her husband was asked to do the act; the reason is to maintain the integrity of their marriage. The request was conveyed by $A$ as a condition for him not to have a special relationship with other women. After that, $\mathrm{V}$ obeyed her husband's wishes. She was afraid of being abandoned by her husband, especially since $V$ doesn't live with her parents. Rayya was the one who became the comfort place at that time. I thought if I refused, I would be scolded. Moreover, the husband kept asking. At first, I refused. But he pressed on, said V at the Garut Police Headquarters, Wednesday (21/8/2019). $V$ doesn't really remember exactly when she first had sex together. She only remembered that in 2017 or 2018 the action was carried out. To be honest, V admitted that she was not comfortable, let alone a spectacle for several people, but she had to be able to enjoy it so that his husband didn't scold him. So, I pretend to enjoy the act. Actually, it's not comfortable, but I have no power to stop, she said. Now $\mathrm{V}$ must go to the court of justice due to the nasty video. She also regretted that she had committed this act, especially since the video has been widely shared in the community.

TribunJabar.id was one of the up to date online media focusing reports on moral violations in Garut which intensively up to right now. TribunJabar.id is still active in reporting these cases to the public. The case of "V Garut" became the focus of news on TribunJabar.id. website. Based on existing data, the pornographic and violent material that happen against 
women and children require more serious handling from the government and the media that report the case. The role of the media as social control must always strive for coverage that has the discourse of reducing and preventing various violations, especially pornographic, and violence material against women (Owens, Behun, Manning, \& Reid, 2012).

Concerning with professionalism in producing news report, journalists must follow the rules and manners in their reporting in the legal field (Wright, 2014). Journalists must comply with the existing code of ethics as stated in article 7 of the Indonesian Journalist Association (Persatuan Wartawan Indonesia - PWI) Journalistic Code of Ethics which states: "Indonesian journalists in reporting events that suspected violations of law and/or judicial processes, must respect the principle of presumption of innocence, principles of fairness, honesty, and balanced" (Kusumaningrat, 2017). The mention of names in journalists' immoral violations is also required to remain their professionalism by referring to the code of ethics stated in Article 9 of the PWI Journalistic Code of Ethics which states: "Journalists in reporting immoral crimes do not harm the victim". In the article, it was explained that journalists were forbidden to publish news that was detrimental to the victim by revealing their identity, which could reduce their dignity. Journalists are only allowed to reveal the age and gender of the victim (Aziz, 2019).

The theory used critical discourse analysis by Teun A. Van Dijk. Van Dijk's model of critical discourse analysis research was used to examine the core information in the news of moral violations on the online news portal TribunJabar.id. According to Van Dijk, research on discourse is not enough to be based only on text analysis, but the production practices carried out by journalists must be observed (Abeele, Campbell, Eggermont, \& Roe, 2014). We have to see how a text is produced so that it raises knowledge about why a text can be like that. If there is a text that marginalizes a woman, then the text must be examined how the production of the text works and why the text marginalizes women, these two things are called social cognition (Eriyanto, 2017).

Text is formed in a discourse practice. Texts that marginalize women are texts presenting a representation that describes a patriarchal culture or social system (Vandenbosch \& Eggermont, 2013a). The micro text describes the marginalization of women in the news, and the macro text explains the patriarchal social structure. Van Dijk connects macro and micro elements which are called social cognition. Social cognition explains how the process of composing the text is produced by journalists, on the other hand, how the patriarchal social structure in society spreads and is understood by journalists who are eventually used to make a news text (Eriyanto, 2017).

This research is in line with the previous research entitled marginalization of women in the career consultation rubric at Kartini magazine: a review of critical discourse analysis. The results of this study indicate that in the text analysis of the macro structure of women depicted in the position of siding with men and being marginalized, generally, Kartini magazine forms the meaning of women's marginalization on its rubric. In the super structured text, there is a journalist attitude to write the discourse naturally. This naturalness is deliberately left to reflect that women are vulnerable and helpless to the problems they deal with. Meanwhile, the microstructure shows that there is an insinuated discourse on woman failure in careers because of her lack of experience. The analysis of social cognition shows that journalists play an active role in shaping the discourse on marginalizing woman (Atwood, 2012). Here a woman is depicted as having weaknesses when she has a career, journalists write about it on purpose. In addition, in social context perspective woman is considered problematic in executing her careers, in society she is perceived losing her achievement, and 
however, the brilliance of a career woman is considered to threaten the men position as dependable figure (Muhammad \& Sumarlam, 2018).

\section{Definition of News}

\section{LITERATURE REVIEW}

News is information that is proper to be presented to the public. Proper means that the news is actual, factual, accurate, objective and important. News is usually a statement published through the mass media. Simply, news stands for North, East, West, and South and become NEWS, which means it has comprehensive information. Information containing news values, and it should be known by the public. News is something new that is chosen by journalists to be published in newspapers. It can be interesting or meaningful and can attract readers of the newspaper (Suryawati, 2014).

\section{News Value}

According to the old theory, the determining factor making news or information is valuable or worthless does not lie in the impact component of the event (Bloom \& Hagedorn, 2015). Several criteria for a news item to be considered valuable include unusual signs, odd objects, new discoveries at the moment, various circumstances, changes in government, problems of war and peace, cause of war, desire to have a war, birth, religious issues, scholar, new sects, decided dogmas, rituals, conflicts, religious conferences, scientific works, masterpiece (Suryawati, 2014). The modern view of news value states that news has value if containing elements of clarity, surprise, closeness, impact and personal conflict. The elements of news value currently used in making news include actuality, closeness, impact, and human interest. Human interest has other elements; they are tension, peculiar thing, personal interest, conflict, sympathy, progress, sex, age, animals, and humour (Anisah, 2016).

\section{Online Media}

Online media is a means of communication which is run by the use of the internet; therefore, online media is a unique medium. The thing that makes it different from other media is that online media requires an information technology network using a computer device to access such information or news (Setianto, 2015). Online media is more advantageous to keep up to date information, this information can be presented at the location of the event directly, and this media is considered practical because it can be accessed anywhere, anytime as long as there is the support of internet facilities (Rachmaniar, Prihandini, \& Janitra, 2018).

The internet functions as a provider of sophisticated data, it means that online media is able to provide speed in sending and receiving information. In addition, online media can be used as a world library that can be accessed through a door called the World Wide Web (www). The online media can be also used as an interpersonal medium to send messages in the form of electronic mail (Suryawati, 2014). The comparison between online media and conventional media in the terms of characteristics and advantages, the online media has unlimited space, it means that there is an unlimited array of information (Kanaker, Abughazlih, \& Kasmani, 2020). 


\section{Teun A. Van Dijk's Critical Discourse Analysis Theory}

There are various models to introduce critical discourse analysis, however, Van Dijk's model is most widely used and developed by experts. Van Dijk elaborates on the elements of discourse so they can be utilized and used practically; this model is often known as social cognition (Rafiqa, 2019). According to Van Dijk, focusing research on discourse is not sufficient if it is only viewed from the text alone, because the text is the result of production practice that must also be observed. Research on discourse cannot exclude as if the text is an empty room, text is a small part of a large social structure. This social cognition approach helps map how text production with this complex process is studied and explained (Eriyanto, 2017). Discourse is a complete language unit and expressed orally in a speech, dialogue, lecture, and so on. In addition, discourse in written form is expressed in a book, magazine, poetry, short story, and so on. In terms of its form, a discourse is cohesive and interrelated with its deep structure and in terms of meaning, it is coherent and integrated (Humaira, 2018).

The text is present as part of a patriarchal representation of society, in this case, there are two parts, they are a micro text which represents the marginalization of women in news and a patriarchal social structure as a common element in society. Van Dijk tries to connect these large elements with micro discourse elements and a dimension known as social cognition (Sakina \& Siti, 2017). This cognition has two meanings, showing how the text process is produced by journalists and how these patriarchal values are spread and perceived by journalists, and finally used to create news (Payuyasa, 2017). Van Dijk sees how the social structure, domination, power that existed in society and how cognition-awareness are formed and influenced given texts. Van Dijk's model of analysis described as follows:

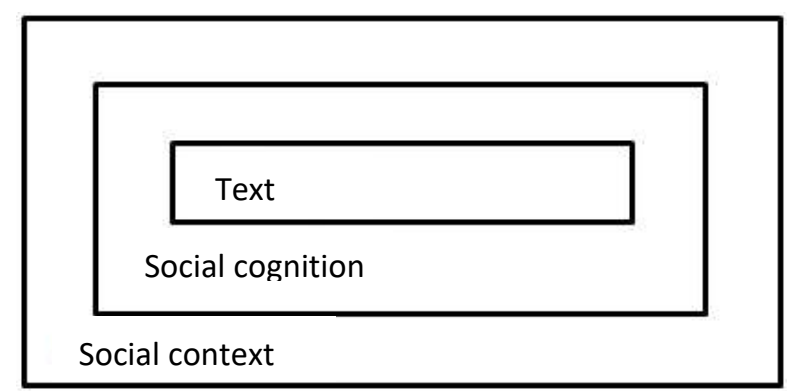

Figure 3: Teun A. Van Dijk model

What is examined in the text dimension is the text structures itself. Van Dijk also uses linguistic analysis of vocabulary, sentences, prepositions and paragraphs to explain and interpret a text. Social cognition is a dimension to explain how a text is produced by individuals or groups of text writers (Setiawan, 2011). The way of seeing a social reality creates a certain text. The emergence of bad news to certain communities arises from a certain pattern of thinking structures framing a way of perceiving a problem so that it influences a text production (Bonino, 2006). Meanwhile, the dimension of social context sees how a text is related to the social structure and knowledge developed in society. These three components are an integral part of van Dijk's model of research and are carried out together (Eriyanto, 2017).

The text structure consists of several levels; each of them supports each other. There are three levels or layers, the first is the macrostructures, it is a general meaning of a text which can be observed by looking at the topics or themes that show in news discourse. Second, the superstructures, it is a discourse structure that is related to text draft, a wellcomposed text component. Third, microstructures, it's a discourse that can be observed from 
a small part of a text, they are words, sentences, propositions, clauses, paraphrases, and pictures (Bonino, 2006).

Table 1: Van Dijk's text structures

Macrostructures. The global meaning of a text that can be observed from the topic or theme of a text Superstructures. The outline of a text, such as the introduction, content, closing remark, and conclusions Microstructures. The local meaning of a text can be observed from the word choice, sentence, and style of a text

The choice of certain words, sentences, propositions and rhetoric composed by the media is perceived by Van Dijk as part of the journalist's strategy. The use of certain words, sentences and styles are not merely seen as a way of communication, but it is a political communication or a way to influence public opinion, create support, strengthen legitimacy, and get rid of opponents or rivals. Discourse structures is an effective way of looking at the rhetoric and persuasion process that is carried out when a person conveys a message (Eriyanto, 2017).

Table 2: Van Dijk discourse elements

\begin{tabular}{|c|c|c|}
\hline Discourse Structure & Object & Elements \\
\hline Macrostructures & Thematic. Theme or topic presented on a news & Topic \\
\hline Superstructures & $\begin{array}{l}\text { Schematic. How news component and order are schemed in } \\
\text { real news }\end{array}$ & Scheme \\
\hline Microstructures & $\begin{array}{l}\text { Semantic. Meaning that is intended to emphasize in a news. } \\
\text { For example, giving a detail on certain part or to make one } \\
\text { side look more explicit than others. }\end{array}$ & $\begin{array}{l}\text { Background, } \\
\text { detail, } \\
\text { intention, } \\
\text { presupposition, } \\
\text { nominalisation }\end{array}$ \\
\hline Microstructures & Syntax. Focusing how a sentence (form and order) is selected & $\begin{array}{l}\text { Sentence form, } \\
\text { coherence, } \\
\text { pronoun }\end{array}$ \\
\hline Microstructures & Stylistic. Seeing how a diction or word choice used in a news & lexicon \\
\hline Microstructures & Rhetoric. Seeing how an emphasis on the news is carried out & $\begin{array}{l}\text { Graphic, } \\
\text { metaphor, } \\
\text { expression }\end{array}$ \\
\hline
\end{tabular}

In addition to text, social cognition is important and becomes an inseparable outline to understand media texts (Eriyanto, 2017). Event is understood and perceived based on a schema; Van Dijk calls this scheme a model as follows: 
Table 3: Van Dijk's schematic model

This scheme describes how a person sees another person. How an

Person scheme Islamic journalist, for example, views Christians who are likely to have an influence on the news that the journalist writes

Self scheme This scheme is related to how oneself is seen, understood, and described by another person

This scheme is related to how a person views and describes the role

Role scheme and position that a person holds in society. For example, how should be the position of men and women in society, and so on. The view of the role that a person should hold in society will influence the news This scheme is probably the most widely used because almost every day we always see, hear events that pass by and we always interpret Event scheme every event in a particular scheme. Generally, this schema of events is the most widely used by journalists

Meanwhile, social context is related to power. Generally, this power is underlined on the possession of any valuable sources such as money, status, and knowledge. Power is understood by Van Dijk has persuasive form, an indirect personal act to control by influencing mental condition, such as belief, attitude and knowledge. A discourse analysis focuses on something dominant. Racism is a form of white domination on the other minority races. Generally, we are also able to analyze how the production process is used to create awareness and consensus (Foust, 2005). The method and schema of the research that can be applied to Van Dijk outline as follow:

Table 4: The research schema and outline method of Van Dijk

\begin{tabular}{lc}
\hline \multicolumn{1}{c}{ Structure } & Method \\
\hline Text. Analyzing how discourse strategy is used to describe a particular & \\
person or event. How a textual strategy is used to eliminate or & Critical linguistics \\
marginalize a group, idea, or event. & \\
Social Cognition. Analyzing how the journalists' cognition in & In-depth interview \\
understanding a certain person or event to be written.
\end{tabular}

\section{Violence against Women}

Violence against women is revealed as a special violation of human rights. The link of violence against women is the key to the human rights violation. Violence against women is genderbased violence and it is not a coincidence that a woman becomes a victim of violence. That's what makes violence against women become an act of discrimination (Fushshilat \& Apsari, 2020). Violence against women can be classified into several forms, such as physical violence, any action causing injury, pain, disability, injury to someone and even death. Sexual violence is an act of harassment against a person to force someone to have sexual intercourse and to have sexual intercourse in a way that is not reasonable or that the victim doesn't like. Psychological violence is action and word causing a person scared, insecure, and helpless. Economic violence is an act to prohibit other people to work inside and outside his home that earns money and goods, letting victim work to be exploited and neglected (Hasbi, 2015).

\section{METHODOLOGY}

This study uses a qualitative approach with a critical paradigm. The critical paradigm looks more deeply at the process of production and reproduction of meaning that occur historically and institutionally. This paradigm emphasizes the constellation of forces in the process of production and reproduction of meaning in discourse. Discourse is perceived as a 
representation that plays a role in shaping certain subject, theme, discourse and strategy. This view is used to disclose the power and strength existed in the language process, they are the boundaries are allowed to be a discourse, the perspectives that should be used, and topics are discussed (Eriyanto, 2017). The researcher determined two informants from the online media, TribunJabar.id and detik.com who worked as journalists. The data collection techniques used are observation, interview and documentation study. Based on the researcher's consideration, the two sources are appropriate as sources of information because they are the people involved in the news production process and they are people who really know about news "V Garut" related to pornography case.

\section{Level of Text Analysis}

\section{RESULTS AND DISCUSSION}

The analysis of text structure of pornography news "V Garut" on the online media of TribunJabar.id in August and September 2019 edition heading: a sad story of "V Garut" forced by her husband to serve other men and to record the act, if she refused, she would scold \& she pretended to enjoy.

Table 5: The text level analysis result on news of "V Garut" in the online media of TribunJabar.id

\begin{tabular}{|c|c|c|c|}
\hline Discourse Structure & Element & Information & Quotation \\
\hline Macrostructure & Topic & News Lead & $\begin{array}{l}\text { Video "V Garut" shocked the public after } \\
\text { being viral last week. The suspect "V Garut" } \\
\text { also gave comment responding to the viral } \\
\text { nasty video. The woman, who was only } 19 \\
\text { years old, married suspect A or Rayya in } \\
2015 \text {. She admitted her husband was asked } \\
\text { to do this act; the main reason is to keep } \\
\text { the integrity of their marriage }\end{array}$ \\
\hline \multirow[t]{4}{*}{ Superstructures } & \multirow[t]{4}{*}{ Schema } & $\begin{array}{l}\text { Summary: } \\
\text { title and news lead }\end{array}$ & $\begin{array}{l}\text { Title: The sad story of "V Garut" asked by } \\
\text { her husband to serve many men \& } \\
\text { recorded, if she refused, she was scolded } \\
\text { and forced to enjoy. } \\
\text { News lead: Video "V Garut" shocked the } \\
\text { public after went viral last week. The } \\
\text { suspect "V Garut" gave comment } \\
\text { responding to the nasty video. The woman, } \\
\text { who was only } 19 \text { years old, married suspect } \\
\text { A or Rayya in } 2015 \text {. She admitted that her } \\
\text { husband was asked to do this act; the main } \\
\text { reason is to keep the integrity of their } \\
\text { marriage }\end{array}$ \\
\hline & & $\begin{array}{c}\text { Story: } \\
\text { paragraph } 2\end{array}$ & $\begin{array}{l}\text { The request was delivered by } A \text { in the order } \\
\text { he would not have another special } \\
\text { relationship with other women. "V Garut" } \\
\text { also complied with her husband's wishes }\end{array}$ \\
\hline & & paragraph 4 & $\begin{array}{l}\text { Paragraph 4: "V Garut" didn't really } \\
\text { remember exactly when she first had sex } \\
\text { together. She only remembered that it } \\
\text { happened in } 2017 \text { or } 2018\end{array}$ \\
\hline & & paragraph 6 & $\begin{array}{l}\text { Paragraph 6: Now "V Garut" must take any } \\
\text { legal consequences for the act. She } \\
\text { regretted that she had committed the act, } \\
\text { especially since the video had gone viral. }\end{array}$ \\
\hline
\end{tabular}




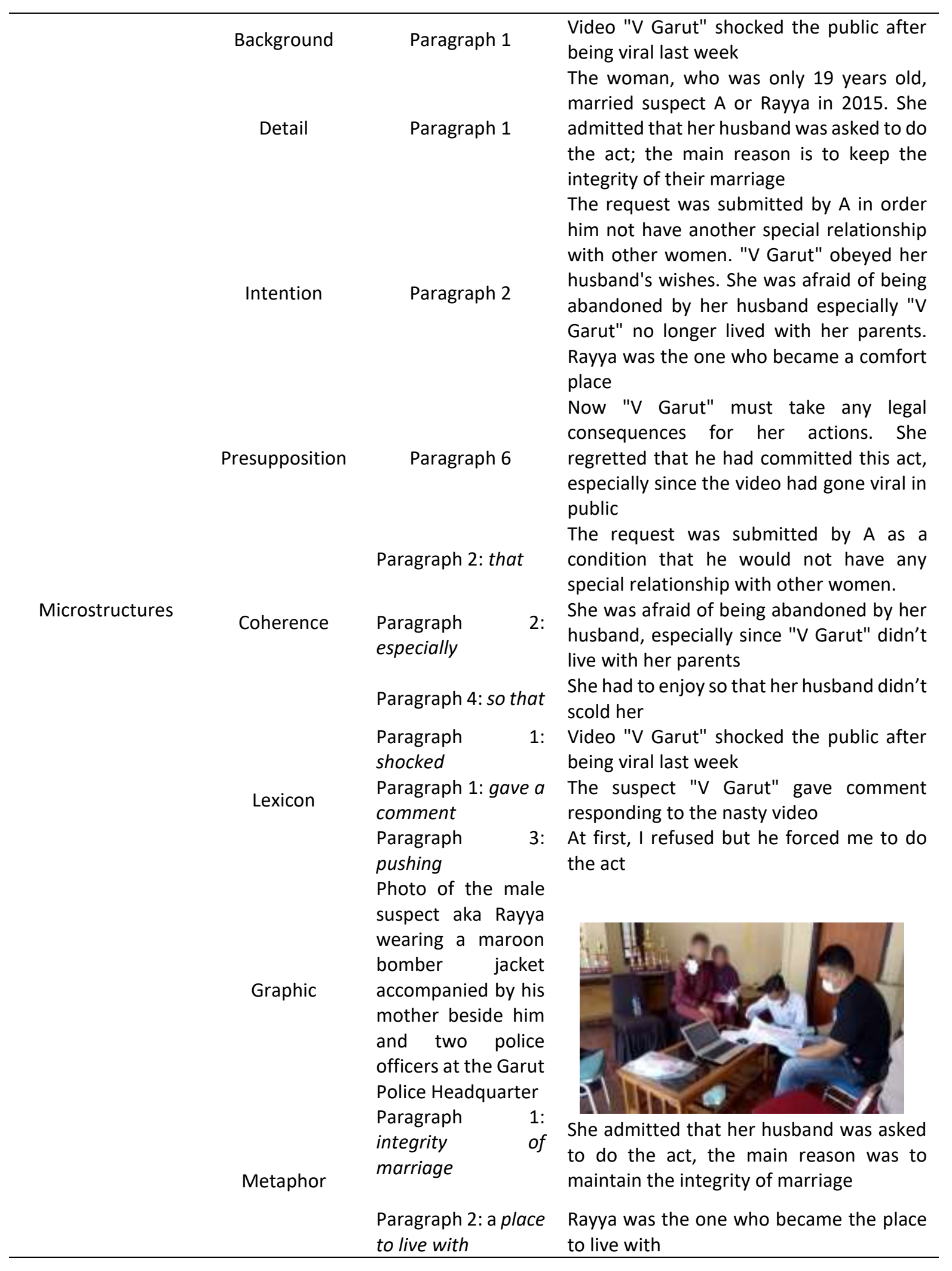

Analysis of the social cognition level in the news "V Garut" on the online media TribunJabar.id The research on social cognition was carried out by conducting interviews with the informant, he is Firman Wijaksana, a TribunJabar.id journalist who has joined TribunJabar.id for seven years and has served as editorial staff and the only TribunJabar.id journalist for Garut area. In addition, the selected informant has competent qualifications in carrying out his profession 
as a journalist. He also has a journalist competence certificate from the Press Council so that he is ensured to have journalist idealism and ability to judge something objectively based on existing facts. In the working place, an informant is a person who is flexible in doing his job; he works out optimally without thinking about the negative stigma that leads to him.

The mental awareness of journalists in viewing the figure of "V Garut" as a woman in this immoral case is known that majority journalists think "V Garut" does not have good social activity and requires recognition in her social neighbourhood. Journalists reveal that economic factor and pressure make "V Garut" a helpless and weak figure that makes her commit immoral acts. Based on the scheme described, then the critical discourse analysis theory of Van Dijk's model can be described as follow:

Table 6: Social cognition model of news "V Garut" on the online media TribunJabar.id

\section{Self-schema}

He is a competent person in doing his profession as a journalist, he also has a journalist competence certificate from the Press Council so that he has journalist idealism and the ability to judge something objectively based on existing facts. Journalists in their working place include people who are flexible in doing their jobs, they work optimally without thinking about the negative stigma directing to them. In addition, in the family environment, we always try to be a leader and have good associations, good relations with neighbours, friends, family, and have good relations with many people

\section{Person-schema}

The informant saw the figure of "V Garut" as a good person but the bad environment led her trapped in the wrong way and needed recognition. In addition, the economic factor and the possibility of pressure from others are the reasons for "V Garut" to commit such immoral acts. Rayya's figure was seen as a graceful person but on the contrary, he was a flexible person and easy to close to anyone, so that led Rayya to become a pimp

\section{Role- schema}

The informant considered that " $V$ Garut" played the role of a suspect or perpetrator, not a victim of violence or trafficking by her husband. It was based on the facts from the Garut Police and the trial. "V Garut" cannot be said to be a victim because she consciously commits the act and she did it frequently. The male suspect, aka Rayya, revealed to be the mastermind of the immoral act. He acted as a pimp by marketing, selling, fixing prices, receiving money, and determining the location of that immoral act

\section{Event-schema}

The informant revealed that the news of "V Garut" was a big and unique case, because of the gang bang action. "V Garut" was paid; even the male suspects did not know each other. This brought the reporter's mind that "V Garut" deserved to be a suspect because she consciously accepted the money and committed the act without rejection. The informant admitted that in this case there were practices of male power over woman, but whatever the reason "V Garut" did the act, she should be able to refuse, according to him the practice of power was not too important in this case. Hence, domestic violence was considered not too prominent because "V Garut" did not seem burdened and when she depressed it was even after the case was busy and facing the law

\section{Analysis of the social context of the news "V Garut" on the online media TribunJabar.id} The third element of Critical Discourse Analysis by Teun A. Van Dijk's model is Social Context. Discourse is something developed dynamically in society, thus to examine a text an intertextual analysis is necessary by examining how a text is produced and constructed in society. According to van Dijk, to know the social context or discourse that develops in society, two important points should be examined, power and access. Critical discourse analysis also pays more attention to the reproduced dominance of providing special access to one group 
over another. As in the news "V Garut" on the online media TribunJabar.id, to find out the discourse that is developing on this news is by analyzing how TribunJabar.id produces and reproduces "V Garut" through attitude, authority and legitimacy.

\section{Practice of Power}

The practice of power conducted by the media appears in the first news explaining the reason "V Garut" commits this immoral act, how did the media expose the inequality in the household life of "V Garut" while there was no direct statement from "V Garut" that she did the act for the sake of household happiness. The second news regarding this case, the practice of power was carried out by highlighting the character "V Garut", detail with the age of "V Garut" who is 19 years old repeatedly. TribunJabar.id statement in the third news showed how the media led opinions to readers, revealed by TribunJabar.id that the two suspects, "V Garut" and Rayya attacked each other by exposing their respective disgrace. It was also said that Rayya exposed his wife's privacy, even though the news content only contained Rayya's denials over the "V Garut" confession.

Besides media, the practice of power occurs in several aspects of life, such as academic, politic, work, economic, law, and sexuality (Maryandi, 2018). Power in legal aspect occurred when "V Garut" became a suspect in making the porn video and was charged under Article 34 as well as Article 8 of Law no. 442008 concerning on pornography without considering other aspects, it is a gender perspective and Article 18 of the Law on Human Trafficking (TPPO) says that "Victims who commit a criminal act because they are forced by the perpetrator of human trafficking, are not convicted." The practice of power also presents on the Law on Information and Electronic Transactions (ITE) in handling this pornography case. The legal aspect that demands "V Garut" is the ITE Law in which "V Garut" is categorized as a model in Garut sex videos that is viral in community. In this case, the ITE Law can easily demand anyone without considering the presence or absence of an act that relates violence with the motive for making immoral videos. If we look back on the previous same case happened, the ITE Law always prosecutes anyone who is considered a victim from criminal acts. The Legal aspect of the ITE Law backfires on anyone considered as a victim. This case of pornography occurred in adolescence, this is a period of finding out self-identity by trying new things, including risky behaviour (Haidar \& Apsari, 2020).

Access is an extension of the power practice; it means that if a person or group has huge power over something, they will have bigger access than those without power who are impossible to have access over something. In the Social Context, access has a direct effect on discourse; the access is legitimacy owned by a person producing discourse. In the case of "V Garut" which has a direct effect in the community is the legal aspect. Relating to the legal process done by Garut Police Headquarter against "V Garut", the National Commission on Violence against Women also took part in handling this case by releasing a recommendation letter regarding the Termination of Police Investigation on "V Garut". The letter numbered 028/KNAKTP/Monitoring/Recommendation Letter/IX/2019 states that "V Garut" is not a suspect but a victim even though she played a role in the porn video. The lawyer for "V Garut" argued that with the existence of this recommendation letter, the investigation of "V Garut" had to be stopped immediately or not continued because the elements were not fulfilled on purpose or with approval. The coercion and threat elements to commit immoral acts concluded that "V Garut" could not be convicted because of being forced and threatened to commit immoral (TribunJabar.id, 2019). However, in fact, the National Commission on Violence against Women did not have access to stop the law process against "V Garut" 
handled by the Garut Police Headquarter. In this case, the police have legitimacy and authority to continue the law process "V Garut" based on the pornography law. This logic persuasively influences the public's view that "V Garut" is a suspect; the stipulation is primarily based on the pornography law mentioning "V Garut" intentionally and agrees to become the object of a pornographic video.

The Police Headquarter of Garut made sure to continue the investigation process even though there was a recommendation letter from the National Commission on Violence against Women because the status of a suspect cannot be revoked just by a recommendation letter. Letter of Termination of Investigation and Prosecution (SP3) can be carried out if there is not sufficient and strong evidence, while for the case of "V Garut" all evidence has completed so that the investigation process continued. Access that influences a discourse is found in the third news of this study, where cover both sides and both parties get the same portion of speech not applied in news-making process. The third news seems unbalanced because it only contained a statement of Rayya's lawyer who stated that the motive for the act was based on the request of "V Garut". Rayya's lawyer has the power to access media so the discourse produced and reproduced in society only implies that Rayya is innocent and that "V Garut" is the mastermind behind the incident.

Concerning on political economy of the media, power has a great influence on the production and reproduction of news, especially in persuasively influencing the views of other people. The political economy perspective of the media cannot be considered separately from the importance of the institution, group and owner of capital as well as a means of power which is influenced by the structure of the political economy itself (Dwita, 2016). In this case, the political economy of the media shows how powerful the interest of Garut Police Headquarter institution in handling and processing the law "V Garut" and other suspects. This interest is related to the image of the police as a security institution which has to take any action in securing everything that makes violence in the community, especially the case of "V Garut". Garut Police Headquarter could not stop the investigation process of "V Garut" because the evidence obtained explained that "V Garut" was actually involved in committing such acts. Based on this finding, if the police stop the investigation process of "V Garut" it will create the negative image of police in society.

Similar to Rayya's lawyer, his interest over the media in news production and reproduction is for the sake of defending Rayya's status in the public view. Through the unbalanced news coverage, it is clear how the media's efforts to influence people's views, especially in increasing Rayya's social status, were previously bad by the community. At least Rayya was not made as blacksheep by many people for exploiting "V Garut". The results of research and discussion can be seen in Chart 1. 


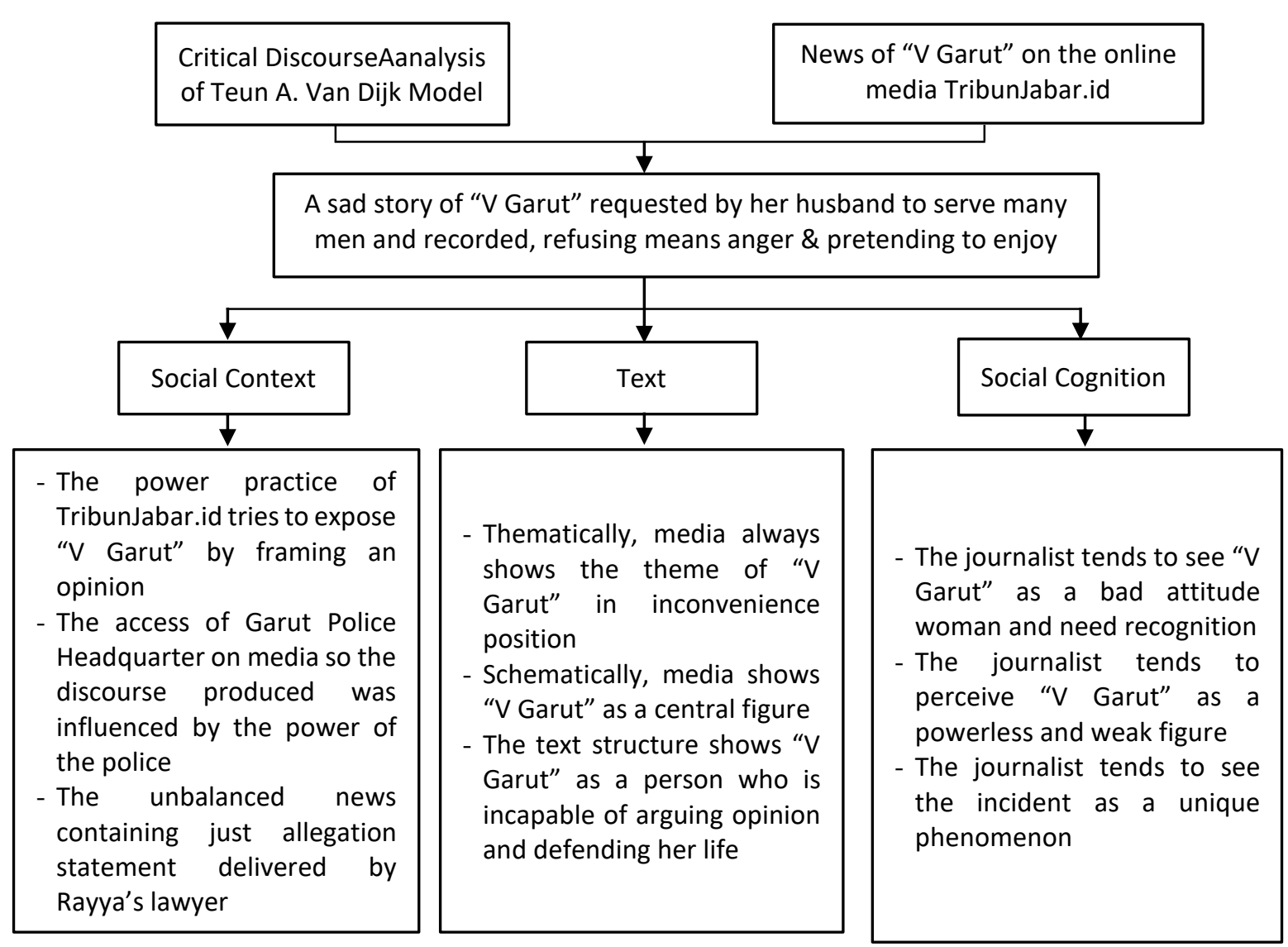

Chart 1: The critical discourse analysis on social context, text and social cognition layers

\section{CONCLUSION}

The text level in news analysis shows that the journalist as if he seems concerned and sympathetic toward the figure of "V Garut" by creating a headline that explains the sad story that happened to a "V Garut" but in fact, the theme captured in the news is inversely proportional to the headline. Journalists commonly describe that "V Garut" is a helpless figure and always has an unfavourable role, such as "V Garut" is completely unable to argue and determine her own fate.

Social cognition or journalist awareness in viewing "V Garut" case has a deviant tendency, in this case, the journalist views that the case has a unique value and is proper to become news. Examining the connotation of word "unique", it has a special positive meaning, so that it means that journalists have a distorted view or awareness because they judge this case based on existing exclusivity, not because there has been a sexual practice which has violated the norms applicable in society such as religious and moral norms.

There are two important points in a social context that develop in society; they are the practice of power and access to influence discourse. First, the practice of power carried out by the TribunJabar.id media is to frame opinions, in this case, it will persuasively influence the reader view with the discourse that has been produced and reproduced, causing and understanding that is incompatible with the existing reality. Meanwhile, on the second point, Garut Police Headquarter has more access to the media. Garut Police Headquarter have the authority to continue the law process "V Garut" despite the recommendation letter for terminating the "V Garut" case released by the National Commission on Violence against Women. Therefore, through the power possessed by Garut Police Headquarter, this access 
affects the developing discourse that "V Garut" deserves to be punished without considering various aspects such as a gender perspective.

\section{BIODATA}

Zikri Fachrul Nurhadi is a lecturer of the Faculty of Communication Sciences, Universitas Garut, Indonesia. Email: zikri_fn@uniga.ac.id

Neneng Cucu Marlina is a lecturer of the Faculty of Communication Sciences, Universitas Garut, Indonesia. Email: nenengcmarlina@uniga.ac.id

Mochamad Firdaus is a lecturer of the Faculty of Communication Sciences, Universitas Garut, Indonesia. Email: mochamadfirdaus121@gmail.com 


\section{REFERENCES}

Abeele, M. V., Campbell, S. W., Eggermont, S., \& Roe, K. (2014). Sexting, mobile porn use, and peer group dynamics: Boys' and girls' self-perceived popularity, need for popularity and perceived peer pressure. Journal Media Psychology, 17(1), 6-33. https://doi.org/10.1080/15213269.2013.801725

Anisah, N. (2016). The effect of pornography on the internet on adolescent behavior in the village. eJournal Ilmu Komunikasi, 4(1), 115-124.

Atwood, K. A. (2012). Correlates of precoital behaviors, intentions and sexual initiation among thai adolescents. Journal of Early Adolescence, 32(3), 364-386. https://doi.org/10.1177/0272431610393248

Aziz, J. (2019). Retrieving trends and issues of penyiaran/broadcasting in Malaysian parliamentary debates from 1957 To 2018: A ulturomics approach. Jurnal Komunikasi: Malaysian Journal of Communication, 35(4), 172-192. https://doi.org/10.17576/JKMJC-2019-3504-11

Bloom, Z. D., \& Hagedorn, W. B. (2015). Male adolescents and contemporary pornography: Implications for marriage and family counselors. Family Journal, 23(1), 82-89. https://doi.org/10.1177/1066480714555672

Bonino, S. C. (2006). Use of pornography and self-reported engagement in sexual violence among adolescents. European Journal of Developmental Psychology, 3(3), 265-288. https://doi.org/10.1080/17405620600562359

Boumosleh, J. M., \& Jaalouk, D. (2017). Depression, anxiety and smartphone addiction in university students: A crosssectional study. Journal Plos One, 12(8), 1-14. https://doi.org/10.1371/journal.pone.0182239

Dwita, D. (2016). Televisi dan kepentingan pemilik modal dalam perspektif teori ekonomi politik media. Jurnal Ipteks Terapan, 257-258. https://doi.org/10.22216/jit.2014.v8i4.21

Eriyanto. (2017). Analisis wacana pengantar analisis teks media. Yogyakarta: LKis Group.

Foust, J. C. (2005). Online Journalism: Principle and practices of news for the web. Indiana: Holcomb Hathaway.

Fushshilat, S. R., \& Apsari, N. C. (2020). Sistem sosial patriarki sebagai akar dari kekerasan seksual terhadap perempuan. Prosiding penelitian dan pengabdian kepada masyarakat (Vol. 7, pp. 121-127). Universitas Padjadjaran, Indonesia. https://doi.org/10.24198/jppm.v7i1.27455

Haidar, G., \& Apsari, N. C. (2020). Pornografi pada kalangan remaja. Jurnal Penelitian Komunikasi, 7(1), 136-143. https://doi.org/10.24198/jppm.v7i1.27452

Hasbi. (2015). Kekerasan terhadap perempuan dalam wacana pemikiran agama dan sosiologi. Al-Tahrir, 15(2), 389-410.

Humaira, H. W. (2018). Analisis wacana kritis model Teun A. Van Dijk pada pemberitaan surat kabar Republikas. Jurnal Literasi, 2(1), 32-40. http://dx.doi.org/10.25157/literasi.v2i1.951

Kanaker, O., Abughazlih, M. O., \& Kasmani, M. F. (2020). Media framing of minorities' crisis: A study on Aljazeera and BBC News coverage of the Rohingya. Jurnal Komunikasi: Malaysian Journal of Communication, 36(2), 1-16. https://doi.org/10.17576/JKMJC2020-3602-01

Kusumaningrat, H. (2017). Jurnalistik teori \& praktik. Bandung: PT Remaja Rosdakarya.

Maryandi, Y. (2018). Pornografi dan pornoaksi: perspektif sejarah dan hukum Islam. Jurnal Peradaban dan Hukum Is/am, 1(1), 21-40. https://doi.org/10.29313/tahkim.vlil.3414 
Muhammad, H. H., \& Sumarlam. (2018). Marjinalisasi wanita pada rubrik konsultasi karir dalam majalah kartini: tinjauan analisis wacana kritis. Jurnal Akrab Juara, 3(3), 226239.

Owens, E. W., Behun, R. J., Manning, J. C., \& Reid, R. C. (2012). The impact of internet pornography on adolescents: A review of the research. Journal Sexual Addiction \& Compulsivity, 19(1-2). https://doi.org/10.1080/10720162.2012.660431

Payuyasa, I. N. (2017). Analisis wacana kritis model Van Dijk dalam program acara mata najwa di Metro TV. Jurnal Segara Widya, 5(1), 14-24. https://doi.org/10.31091/sw.v5i0.188

Peter, J., \& Valkenburg, P. M. (2016). Adolescents and pornography: A review of 20 years of research. The Journal of Sex Research, 53(4-5), 509-531. https://doi.org/10.1080/00224499.2016.1143441

Rachmaniar, R., Prihandini, P., \& Janitra, P. A. (2018). Perilaku penggunaan smartphone dan akses pornografi di kalangana remaja perempuan. Jurnal Komunikasi Global, 7(1), 111. https://doi.org/10.24815/jkg.v7i1.10890

Rafiqa, S. (2019). Comparison of the model critical discourse analysis by Mills and Fairclough at online media in case reporting of "ikan asin". Jurnal Pendidikan Bahasa dan Sastra Indonesia, 3(2), 73-80. https://doi.org/10.30998/jh.v3i2.218

Sakina, A. I., \& Siti, D. H. (2017). Menyoroti budaya patriarki di Indonesia. Social Work Jurnal, 7(1), 71-80. https://doi.org/10.24198/share.v7i1.13820

Setianto, Y. P. (2015). Media policy in the context of global media flows, the internet, and piracy: An historical analysis of media regulation in Indonesia. Jurnal Komunikasi: Malaysian Journal of Communication, 31(2), 371-388. https://doi.org/10.17576/JKMJC-2015-3102-21

Setiawan, Y. B. (2011). Analisis wacana kritis pemberitaan kekerasan berbasis gender di surat kabar harian suara merdeka. Jurnal Ilmiah Komunikasi Makna, 2(1), 13-20. http://dx.doi.org/10.30659/jikm.2.1.13-20

Suryawati. (2014). Jurnalistik suatu pengantar. Bogor: Ghalia Indonesia.

Susilo, A. G. (2015). Perempuan dan narasi kekerasan: Studi kritis peran gender dalam deradikalisasi. Jurnal Tasawuf dan Pemikiran Islam, 5(2), 431-454. https://doi.org/10.15642/teosofi.2015.5.2.431-454

TribunJabar.id. (2019, Desember Kamis). Jumlah kasus kekerasan terhadap anak di Garut cukup tinggi, beberapa pelaku merupakan orang terdekat. Retrieved from https://jabar.tribunnews.com/2019/12/19/jumlah-kasus-kekerasan-terhadap-anakdi-garut-cukup-tinggi-beberapa-pelaku-merupakan-orang-terdekat

Tribunnews.com. (2019, September Jumat). Menteri Yohana: Indonesia darurat pornografi, kita harus jaga anak-anak. Retrieved from https://www.tribunnews.com/nasional/2019/09/06/menteri-yohana-indonesiadarurat-pornografi-kita-harus-jaga-anak-anak

Tribunnews.com. (2019, Agustus Rabu). Usai jual istri buat video Vina Garut, Rayya kena stroke dan penyakit yang serang kekebalan tubuh. Retrieved from https://www.tribunnews.com/regional/2019/08/21/usai-jual-istri-buat-video-vinagarut-rayya-kena-stroke-dan-penyakit-yang-serang-kekebalan-tubuh?page=3

Tribunnews.com. (2020, Januari Jumat). 244.738 Konten pornografi dilaporkan ke Kominfo sepanjang $2019 . \quad$ Retrieved from https://www.tribunnews.com/techno/2020/01/10/244738-konten-pornografidilaporkan-ke-kominfo-sepanjang-2019 
Tribunnewswiki.com. (2019, Agustus Kamis). 10 pengakuan langsung Vina, perempuan dalam video Vina Garut 3 lawan 1: Saya dipaksa menikmati. Retrieved from https://www.tribunnewswiki.com/2019/08/22/10-pengakuan-langsung-vinaperempuan-dalam-video-vina-garut-3-lawan-1-saya-dipaksa-menikmati

Vandenbosch, L., \& Eggermont, S. (2013a). Sexualization of adolescent boys: Media exposure and boys' internalization of appearance ideals, self-objectification, and body surveillance. Journal Men and Masculinities, 16(3), 283-306. https://doi.org/10.1177/1097184X13477866

Wright, P. J. (2014). Pornography and the sexual socialization of children: Current knowledge and a theoretical future. Journal of Children and Media, 8(3), 305-312. https://doi.org/10.1080/17482798.2014.923606

Ybarra, M. L., \& Mitchell, K. J. (2014). Sexting and its relation to sexual activity and sexual risk behavior in a national survey of adolescents. The Journal of Adolescent Health: Official Publication of the Society for Adolescent Medicine, 55(6), 757-764. https://doi.org/10.1016/j.jadohealth.2014.07.012 